\title{
Kinetic Study of Sulfur Dioxide Elimination by Limestone through the Lab Scale Circulating Fluidized Bed Combustor
}

\author{
Dowon Shun*, Dal-Hee Bae *, In-Kyu Jang**, Keon-Hee Park** and Seung Kyu Park**, ${ }^{*}$ \\ "Greenhouse Gas Research Center, \\ Korea Institute of Energy Research, 71-2 Daejon 305-343, Korea \\ "Department of Chemical Engineering, \\ Hoseo University, Asan 336-795, Korea \\ Email : skpark@hoseo.edu
}

\begin{abstract}
Characteristics of sulfur dioxide emission from coal and petroleum coke combustion were examined in a lab scale circulating fluidized bed (CFB) combustor. The rate constant of the first order rate expression for the absorption $\mathrm{SO}_{2}$ on the $\mathrm{CaO}$ surface was similar regardless of the origin of the limestone, the particle size and the initial $\mathrm{SO}_{2}$ concentration. However, the total $\mathrm{SO}_{2}$ absorption capacity was different depending on the origin of the limestone. The breakability of the particle which provides new surface for the reaction seems to play a major role in the absorption characteristics.
\end{abstract}

Keywords-Sulfur Dioxide (SOx); Limestone; Circulating Fluidized Bed Combustor; Emission; Kinetics; First order reaction

\section{Introduction}

Sulfur oxides $\left(\mathrm{SO}_{\mathrm{x}}\right)$ gases form when the coal and heavy oil are burned. The $\mathrm{SO}_{2}$ readily dissolves in water vapor and leads to the formation of acid and interacts with other gases and particles in the air to form sulfates and other products that can be harmful to people and environment $[1,2]$. $\mathrm{SO}_{2}$ pollution is thought to promote wheezing, bronchial constriction, shortness of breath, and exacerbation of asthma [2]. Nitrogen oxides $\left(\mathrm{NO}_{\mathrm{x}}\right)$ are highly reactive gases that contain nitrogen and oxygen in varying molecular combinations. The major source of $\mathrm{NO}_{\mathrm{x}}$ is the combustion of fossil fuels such as coke in electric power plants or petroleum in vehicle engines [3]. Many of the nitrogen oxides are colorless, but nitrogen dioxide $\left(\mathrm{NO}_{2}\right)$ combined with particles in the air can cause a reddish-brown haze. The presence of $\mathrm{NO}_{\mathrm{x}}$ leads to a variety of environmental problems such as ground level ozone, acid rain and the deforestation by acid rain. They are poisonous for the respiratory system, provoking both lung infection and respiratory allergies. Both sulfur dioxide and nitrogen oxides contribute to acid rain [4]. Just a few decades ago, $\mathrm{SO}_{\mathrm{x}}$ and $\mathrm{NO}_{\mathrm{x}}$ pollution had gotten so bad that acid rain had damaged countless buildings, monuments, car finishes [5]. One member of the $\mathrm{NO}_{\mathrm{x}}$ family, nitrous oxide $\left(\mathrm{N}_{2} \mathrm{O}\right)$, is a potent greenhouse gas [6]. Air pollution caused by $\mathrm{SO}_{\mathrm{x}}$ and $\mathrm{NO}_{\mathrm{x}}$, which are largely the result of industrial processes, may also produce environmental impacts. For these reasons, $\mathrm{SO}_{\mathrm{x}}$ and $\mathrm{NO}_{\mathrm{X}}$ emissions should be eliminated.

In the field of fluidized bed combustion with high thermal capacities, circulating fluidized bed (CFB) reactors are considered to be the most efficient commercial utility which burns various solid fuels, including coals, with a minimum operation and maintenance cost [7-9]. The reactors are usually lack of sulfur capture facilities, such as flue gas treatment, since the in-situ $\mathrm{SO}_{2}$ capture by the limestone injection into the combustor itself is sufficient to comply with the regulation. Although the best operation parameters for the boilers could be collected from the actual experience of the commercial scale boilers [10], the information is not always intuitive since the parameters of the commercial boilers in operation are normally interrelated. It is quite difficult to understand the actual effects of specific variables on the performance of the commercial boiler in operation. On the other hand, many experimental results from previous researches were carried out with packed bed units in small scale and turned out to be impractical to be applied to the commercial CFB boilers [3]. To investigate the emission characteristics of CFB systematically, a CFB combustor was built in-house grade. Many researchers have been performed in conventional air-combustion fluidized bed boilers to eliminate the $\mathrm{SO}_{\mathrm{x}}$ by limestone flux, and much information has been accumulated through the kinetic and spectroscopic studies, many basic questions still remain to be answered clearly. The emission of $\mathrm{SO}_{\mathrm{x}}$ and $\mathrm{NO}_{\mathrm{x}}$ gases during the combustion of coal or petroleum pitch in the CFB has been studied. The aim of this study is to elucidate the absorption of $\mathrm{SO}_{2}$ by three kinds of limestone produced from Tanyang, Samchuk and Jinsan in Korea. Emission of $\mathrm{SO}_{\mathrm{x}}$ and $\mathrm{NO}_{\mathrm{x}}$ in the CFB and reaction of them with limestone have been investigated.

\section{Experimental}

\section{A. Circulated fluidized bed}

The circulated fluidized bed (CFB) combustor was prepared with quarts tubes [8-10]. The CFB combustor consists of a riser (combustion chamber) and a cyclone, a loop seal and an ash classifier. The silica sand in the riser was heated to more than $900^{\circ} \mathrm{C}$ and was blown upward by the combustion air from 
the bottom of the riser to the top. Since the heat generated from the combustion of coals was not sufficient to sustain the desired combustor temperature, multi sets of electric heaters were installed around the outer side of the test unit.

\section{B. Sulfur dioxide capture by limestone and analysis}

Test coal samples were screened with the particle size between 0.1-0.7 $\mathrm{mm}$. In the combustion experiments were tested five different coal samples;

1) Blair Athol coal: a bituminous coal from Australia

2) Herbei coal : a high sulfur bituminous coal widely used in the power industries of China

3) Shenhwa coal : a low sulfur, high heating value coal from China

4) Tokye coal : a Korean anthracite

5) Petroleum coke : a byproduct from a Korean refinery

The combustor installed with bed materials was heated with air only to the pre specified temperature by electric heaters. As the temperature of the combustor reached the pre-set value, the coal was fed into the bottom of the riser. While the coal was burned inside of the riser, the ashes were entrained to the top of the combustor and led to the cyclone. The particles except very fine ashes were collected by the cyclone and recycled to the riser through the return leg. The particles were circulated between the riser and the return leg until the combustion is completed and the particle size is reduced enough to flow out of the cyclone to the bag filter. The effluent from the cyclone to the bag filter was analyzed by the URAS Model 14-1, 14-2 of ABB Hartman and Braun to measure the levels of $\mathrm{SO}_{2}, \mathrm{NO}_{x}$, $\mathrm{N}_{2} \mathrm{O}, \mathrm{CO}, \mathrm{CO}_{2}$, and $\mathrm{O}_{2}$. The limestone was feeding by $50 \mathrm{~g}$ to $\mathrm{CFB}$ reactor. The limestone was calcined in a muffle furnace at $900{ }^{\circ} \mathrm{C}$ for 2 hours.

\section{Results and Discussion}

The design specifications of the CFB are listed in Table 1. In the combustion test of coal samples, only the air/fuel ratio was varied while the operation temperature is fixed. However both the operation temperature and the air/fuel ratio were fixed for the investigation of the sulfur capture kinetics. Furthermore the variation of the reactor temperature and the air/fuel ration were restricted to be varied within the precision limit of the facility while the coal feed rate was varied between 0.1 and $0.2 \mathrm{~kg} / \mathrm{min}$.

Table 1. Design specification of the quartz CFB.

\begin{tabular}{|c|c|c|}
\hline Parameter & Minimum & Maximum \\
\hline Coal, kg/h & 0.16 & 0.24 \\
\hline Air flow LPM $@$ stp & 22 & 28 \\
\hline $\mathrm{O}_{2}$ in flue gas, $\%$ & 2 & 7 \\
\hline Velocity of gas, $\mathrm{m} / \mathrm{s}$ & 5 & 6 \\
\hline Average bed temp, K & 1123 & 1173 \\
\hline
\end{tabular}

Table 2 presents the compositions of each Korean limestone utilized in the experiment. All three samples are typical commercial products and currently used for the commercial CFB boilers in Korea. The $\mathrm{CaO}$ contents were between $51-55 \%$, and the purities were similar. Limestones were activated after the calcinations in the CFB combustor. Figure 1 shows the SEM images of the Jinsan limestone before and after the calcination. The limestone was calcined in a muffle furnace at $900{ }^{\circ} \mathrm{C}$ for 2 hours. After the calcination, $\mathrm{CO}_{2}$ on the $\mathrm{CaCO}_{3}$ was detached and the $\mathrm{CaO}$ surface was exposed with the generation of many small pores. The wrinkled $\mathrm{CaO}$ surface was known to provide $\mathrm{SO}_{2}$ absorption sites on which reactions occur $[3,4]$.

Table 2. The main composition of three limestones.

\begin{tabular}{|c|c|c|c|}
\hline \multirow{2}{*}{ Component } & \multicolumn{3}{|c|}{ Limestone } \\
\cline { 2 - 4 } & Tanyang & Samchuk & Jinsan \\
\hline $\mathrm{CaO}$ & 53.13 & 54.25 & 51.6 \\
\hline $\mathrm{MgO}$ & 0.94 & 0.36 & 0.39 \\
\hline $\mathrm{CO}_{2}$ & 42.72 & 42.97 & 40.92 \\
\hline
\end{tabular}

(a)

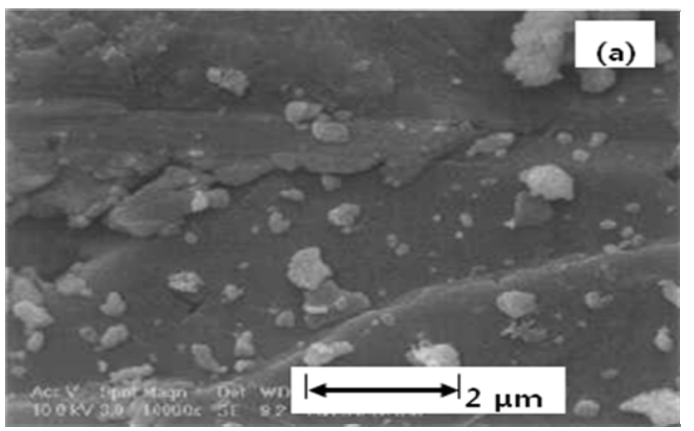

(b)

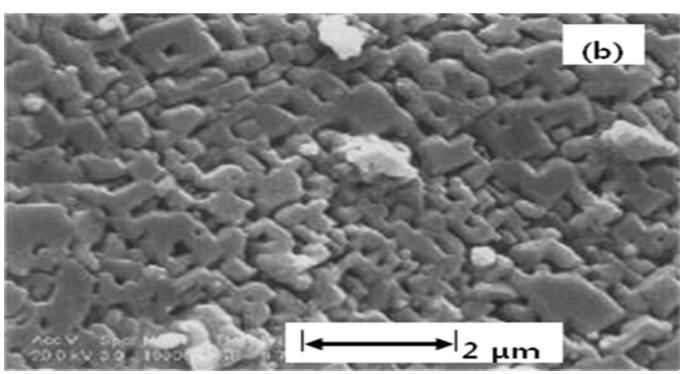

Figure 1. SEM image of T limestone (a) before and (b) after calcination.

Table 3 presents the BET surface analysis by a Quantachrome Autosorb 1 with the absorption of nitrogen gas at its boiling temperature.

Table 3. BET surface analysis of limestone.

\begin{tabular}{|l|l|l|}
\hline Sam- & $\mathrm{CaCO}_{3}$ & $\mathrm{CaO}$ after calcination \\
\hline
\end{tabular}




\begin{tabular}{|c|c|c|c|c|c|c|}
\hline ple & $\begin{array}{c}\text { Area } \\
\left(\mathrm{m}^{2} / \mathrm{g}\right)\end{array}$ & $\begin{array}{c}\text { Vol. } \\
\left(\mathrm{cm}^{3} /\right. \\
\mathrm{g})\end{array}$ & $\begin{array}{c}\text { Pore } \\
\text { dia. } \\
(\mu \mathrm{m})\end{array}$ & $\begin{array}{c}\text { Area } \\
\left(\mathrm{m}^{2} / \mathrm{g}\right)\end{array}$ & $\begin{array}{c}\text { Vol. } \\
\left(\mathrm{cm}^{3} /\right. \\
\mathrm{g})\end{array}$ & $\begin{array}{c}\text { Pore } \\
\text { dia. } \\
(\mu \mathrm{m})\end{array}$ \\
\hline $\begin{array}{c}\text { Tan- } \\
\text { yang }\end{array}$ & 0.53 & 0.15 & 1.13 & 6.77 & 2.21 & 1.30 \\
\hline $\begin{array}{c}\text { Sam- } \\
\text { chuk }\end{array}$ & 0.28 & 0.09 & 1.30 & 11.24 & 3.66 & 1.30 \\
\hline $\begin{array}{c}\text { Jin- } \\
\text { san }\end{array}$ & 0.41 & 0.12 & 1.17 & 1.85 & 0.59 & 1.28 \\
\hline
\end{tabular}
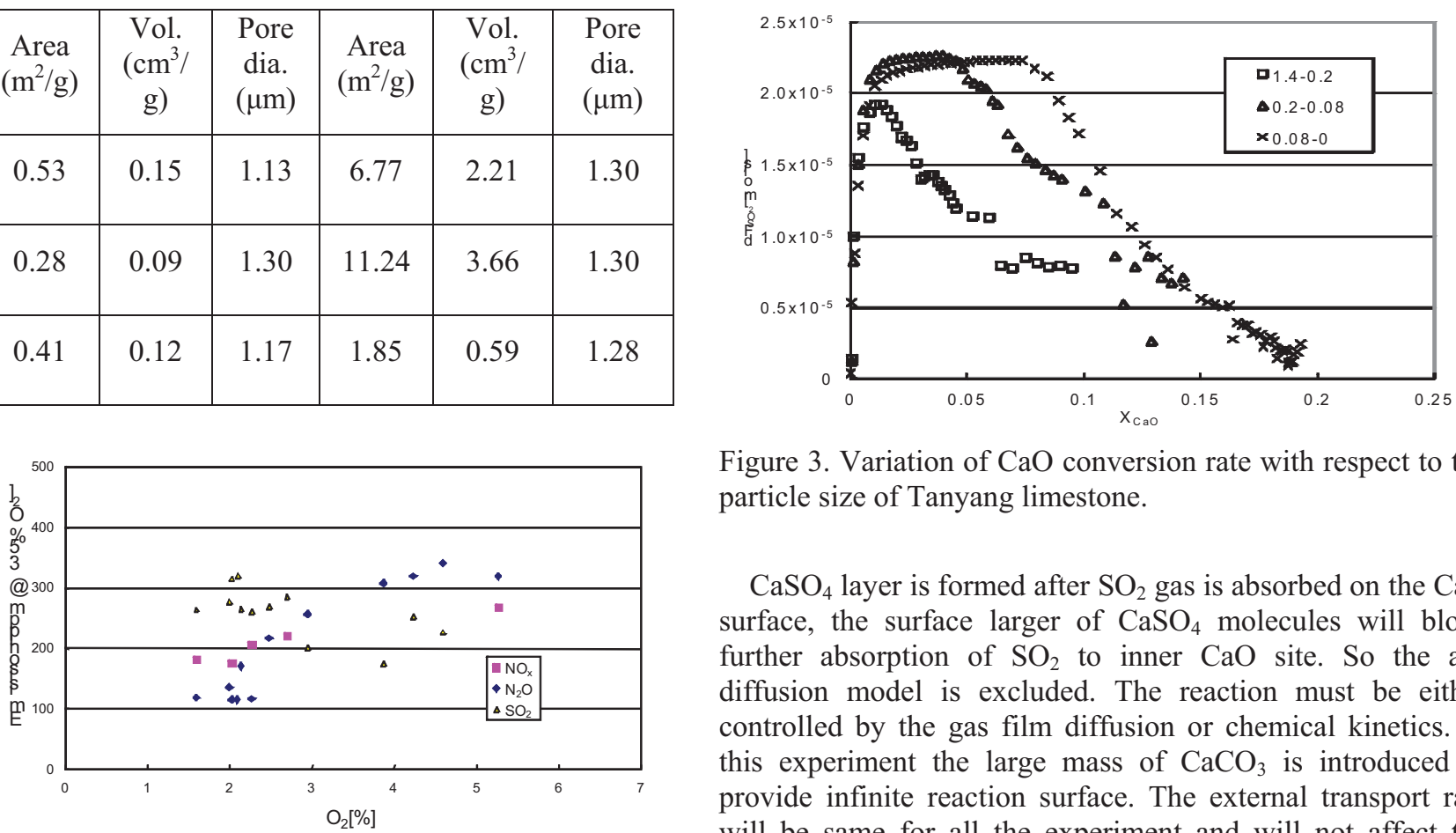

Figure 3. Variation of $\mathrm{CaO}$ conversion rate with respect to the particle size of Tanyang limestone.

$\mathrm{CaSO}_{4}$ layer is formed after $\mathrm{SO}_{2}$ gas is absorbed on the $\mathrm{CaO}$ surface, the surface larger of $\mathrm{CaSO}_{4}$ molecules will block further absorption of $\mathrm{SO}_{2}$ to inner $\mathrm{CaO}$ site. So the ash diffusion model is excluded. The reaction must be either controlled by the gas film diffusion or chemical kinetics. In this experiment the large mass of $\mathrm{CaCO}_{3}$ is introduced to provide infinite reaction surface. The external transport rate will be same for all the experiment and will not affect the reaction rate. The gas film diffusion control mechanism and the chemical reaction control mechanism were compared and the chemical reaction control showed better fit to the data.

A second order absorption kinetics was proposed to analyze the experimental data.

$r=k C_{\mathrm{SO}_{2}} C_{\mathrm{CaO}}$

Where, $r ; \mathrm{SO}_{2}$ absorption rate [gmol $\mathrm{SO}_{2} /$ gmol limestone-s]

$k ; 2$ nd order rate constant [liter/gmol CaO-s]

$C_{C a O}$; Concentration of $\mathrm{CaO}$

[gmol CaO/gmol limestone]

Figure 2. The effects of the aeration on the emissions of $\mathrm{SO}_{2}$, $\mathrm{NO}_{\mathrm{x}}$ and $\mathrm{N}_{2} \mathrm{O}$ from the combustions of (a) the Blair Athol coal and (b) the Tokye coal.

In the Blair coal combustion, about $280 \mathrm{ppm}$ of $\mathrm{SO}_{2}$ emission was slightly decreased to $200 \mathrm{ppm}$ as the oxygen content increases. Meanwhile, the $\mathrm{N}_{2} \mathrm{O}$ emission was slightly increased from $110 \mathrm{ppm}$ to $310 \mathrm{ppm}$ as the oxygen feeding was increased. In the Tokye coal combustion, the $\mathrm{SO}_{2}$ emission gradually was decreased from $500 \mathrm{ppm}$ to $400 \mathrm{ppm}$ as the oxygen feeding increases. Figure 3 shows the variation of $\mathrm{CaO}$ conversion rate of Tanyang limestone as the reaction goes by. The comparison was made among different average particle sizes. The maximum conversion rates were observed when $\mathrm{CaO}$ conversion, $\mathrm{X}_{\mathrm{CaO}}$, was $0-0.1$. After that it decayed rapidly.

$$
\begin{gathered}
C_{\mathrm{SO}_{2}} \text {; Concentration of } \mathrm{SO}_{2} \text { at the combustor exit } \\
{\left[\mathrm{gmol} \mathrm{SO}_{2} /\right. \text { liter] }}
\end{gathered}
$$

The kinetic equations can be restated as;

$$
d F_{\mathrm{SO}_{2}}=k C_{\mathrm{SO}_{2}} F_{\mathrm{CaO}}
$$

$$
\text { Where } d F_{\mathrm{SO}_{2}}=d F_{\mathrm{CaO}}[\mathrm{gmol} \mathrm{SO} / \mathrm{s}]
$$

Since the excess amount of $\mathrm{CaO}$ was injected in the reactor. The concentration of $\mathrm{CaO}$ in the circulating fluidized bed combustor is considered to be constant and the reactor is considered as a mixed reactor regarding $\mathrm{CaO}$. The reactor equation is the first order only to the concentration of $\mathrm{SO}_{2}$. $r=k^{\prime} C_{S O 2} \quad$ Where, $k^{\prime} ; 1$ st order rate constant $[1 / \mathrm{s}]$.

When the $\mathrm{SO}_{2}$ absorption rate of limestone with different origin is compared, the Jinsan limestone showed the highest rate constant and that of Samchuk showed the lowest constant. 
For understanding of $\mathrm{SO}_{2}$ gas adsorption onto limestone, the chemical reaction model should be studied [5, 12]. For the comparison of the rate controlling step, we postulate that the particle is a globular shape at the shrinking core model during the adsorption of gas onto the particle.

At the reaction : A (gas) + B (soild) -> Solid Products

$$
\begin{aligned}
-\frac{1}{S_{E x}} \frac{d W_{E}}{d t} & =-\frac{1}{4 \pi R^{2}} \frac{d N_{D}}{d t}=-\frac{b}{4 \pi R^{2}} \frac{d N_{A}}{d t} \\
& =b k_{g}\left(C_{A g}-C_{A g}\right)=b k_{g} C_{A g}
\end{aligned}
$$

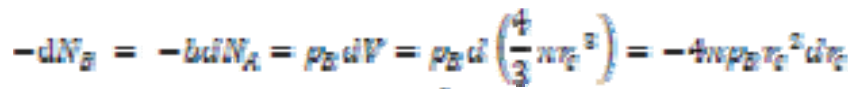

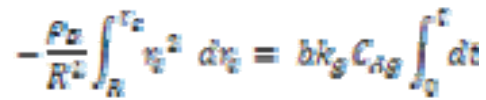

$\tau=\frac{\theta_{\pi} R}{\mathrm{a} \hat{R}_{G} C_{A S}}$

$\frac{t}{r}=1-\left(\frac{r}{R}\right)^{2}=x$

In the case of kinetic control,

$-\frac{1}{4 \pi \eta^{2}} \frac{d W_{E}}{d t}=-\frac{b}{4 \pi \eta^{2}} \frac{d N_{k}}{d t}=b k_{g} C_{K a}$

Therefore,

$\frac{\tau}{\tau}=1-\frac{r}{R}=1-(1-x)^{\frac{1}{2}}$

Figure 4 shows the $\mathrm{CaO}$ conversion curve fitting with respect to the reaction time. It is clearly seen that the slope of time versus $(1-x)^{\frac{3}{2}}$ is linear and close to 1 , the reaction follows gas film diffusion control.

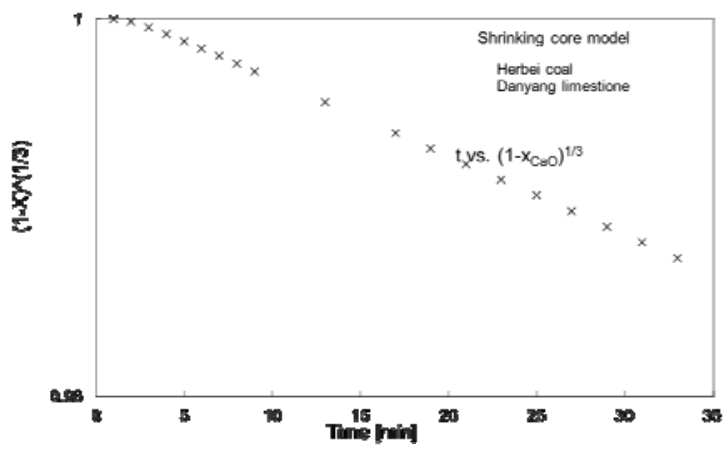

Figure 4. $\mathrm{CaO}$ conversion curve fitting to the shrinking core model.
Sulfur elimination by limestone under CFB combustion conditions is the net effect of a competition between sulfur capture and sulfur release during which the composition of the $\mathrm{Ca}$ surface changes continuously between $\mathrm{CaO}, \mathrm{CaS}$ and $\mathrm{CaSO}_{4}$. Therefore, we conclude that the limestone feeding is enough to capture all $\mathrm{SO}_{2}$ gases, so the reactions become depend on the concentration of $\mathrm{SO}_{2}$. And the reaction can be disrupted by the formation of $\mathrm{CaSO}_{4}$ after reaction goes by.

\section{Conclusion}

The $\mathrm{CaO}$ contents of three kinds of limestone were between $51-55 \%$. The BET surface area of Samchuk limestone was increased about 40 times after calcinations. The surface area of Samchuk $\mathrm{CaCO}_{3}$ was increased from $0.28 \mathrm{~m}^{2} / \mathrm{g}$ to $11.24 \mathrm{~m}^{2} / \mathrm{g}$ after the calcinations to $\mathrm{CaO}$ at $900{ }^{\circ} \mathrm{C}$ for 2 hours at the $\mathrm{CFB}$ combustor. Based on the kinetic study of $\mathrm{SO} 2$ gas adsorption to $\mathrm{CaO}$ solid, the $\mathrm{CaO}$ conversion curve fits with respect to the reaction time. Since the slope of time versus $(1-x)^{\frac{1}{2}}$ is linear and close to 1 , it follows gas film diffusion control. We suggest that the reaction is the first order. Since the limestone feeding is enough to capture all $\mathrm{SO}_{2}$ gases, the reaction become depend on the concentration of $\mathrm{SO}_{2}$. And the reaction can be disrupted by the formation of $\mathrm{CaSO}_{4}$ after reaction goes by.

\section{REFERENCES}

[1] F. Garcia-Labiano, A. Rufas, L. F. de Diego, M. de las ObrasLoscertales, P. Gayan, and J. Adanez, Fuel, 90, 3100 (2011).

[2] G. Ozkan, and G. Dogu, Chem Engineering and Processing, 41, 11 (2002)

[3] S. K. Park, V. Kurshev, Z. Luan, C. W. Lee, and L. Kevan, Micropor. Mesopor. Mater., 38, 255 (2000).

[4] D. R. M. Wright, F. Pinto, L. Armesto, M. A. Caballero, M. P. Aznar, A. Cabanillas, Y. Huang, C. Franco, I. Gulyurtle, and J. T. McMullan, Fuel Processing Technol. 87, 793 (2006).

[5] M. Higashi, S. Uchida, N. Suzuki, and K. I. Fujii, IEEE Trans. on Plasma Sci., 20, 1 (1992)

[6] D. Shun, D. H. Bae, J. Y. Paek, and Y. S. Park, Korean J. Chem. Eng. 21, 890 (2004).

[7] D. Shun, D. H. Bae, K. H. Han, S. H. Cho, and S. Y. Lee, Hwahak Konghak 40, 345 (2002).

[8] D. R. M. Wright, F. Pinto, L. Armesto, M. A. Caballero, M. P. Aznar, A Cabanillas, Y. Huang, C. Franco, I. Gulyurtle, and J. T. McMullan, Fuel Processing Technol. 87, 793 (2006).

[9] K. Redemann, E. U. Hartge, and J. Werther, Fuel, 87, 3669 (2008)

[10] D. Shun, H. S. Chang, T. S. Park, D. H. Bae, and G. T. Jin, Korean J. Chem. Eng., 18, 630 (2001).

[11] P. Gayan, J. Adanez, L. F. de Diego, F. Garcia-Labiano, A. Cabanillas, A. Bahillo, M. Aho, and K. Veijonen, Fuel, 83, 277 (2004).

[12] L. Jia, J. Wang, and E. J. Anthony, Chem. Eng. J., 94, 147 (2003). 